\title{
The Shape of Alluvial Channels in Relation \\ To Sediment Type
}

GEOLOGIGAL SURVEY PROFESSIONAL PAPER 352-B

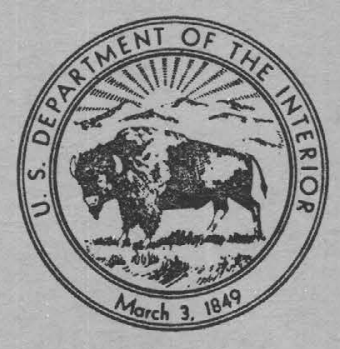





\section{The Shape of Alluvial}

Channels in Relation

To Sediment Type

By S. A. SCHUMM

EROSION AND SEDIMENTATION IN A SEMIARID ENVIRONMENT

GEOLOGICAL SURVEY PROFESSIONAL PAPER 352-B

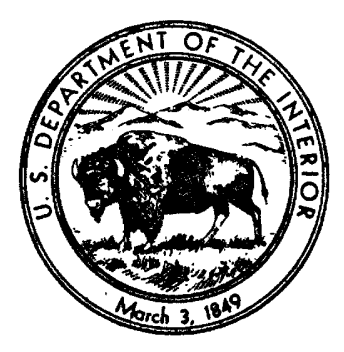

UNITED STATES GOVERNMENT PRINTING OFFICE, WASHINGTON : 1960 


\section{UNITED STATES DEPARTMENT OF THE INTERIOR \\ STEWART L. UDALL, Secretary \\ GEOLOGICAL SURVEY}

Thomas B. Nolan, Director

Reprinted, 1961

For sale by the Superintendent of Documents, U.S. Government Printing Office

Washington 25, D.C. - Price 35 cents (paper cover) 


\section{CONTENTS}

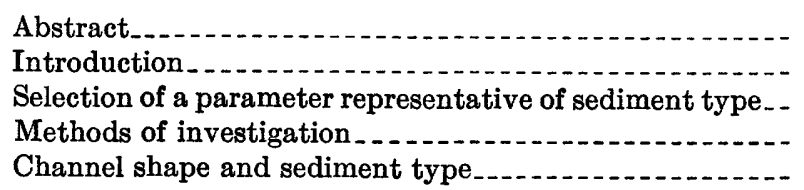

Page

\section{L L U S T R A T I O N S}

Plate 5. Stream channels illustrating range of channel characteristics at measured cross sections._...

FIGURE 8. Relation between width-depth ratio and weighted mean percent silt-clay $(M)$

9. Relation between channel width and weighted mean percent silt-clay $(M)$

10. Relation of width-depth ratio to weighted mean percent silt-clay $(M)$ for unstable cross sections .................

11. Relation between width-depth ratio and weighted mean percent silt-clay $(M)$ for cross sections with channel floor covered by more than 40 percent gravel, cobbles and boulders

12. Relation of width-depth ratio to $M$ along the Smoky Hill-Kansas River.

13. Relation between width and depth for streams with not greatly different values of $M$ in a downstream direction.-

14. Relation of channel width to depth for the Smoky Hill-Kansas River

15. Relation of channel width to mean annual discharge for the Smoky Hill, Republican and Kansas Rivers...-..

16. Relation of channel maximum depth to mean annual discharge for the Smoky Hill, Republican and Kansas Rivers

\section{T A B L E}




\title{
THE SHAPE OF ALLUVIAL GHANNELS IN RELATION TO SEDIMENT TYPE
}

\author{
By S. A. SсHUMm
}

\begin{abstract}
The weighted mean percent silt-clay in the channel and banks of stable alluvial stream channels is used as a parameter $(M)$ descriptive of the physical characteristics of sediment. Silt-clay is defined as alluvial material smaller than $0.074 \mathrm{~mm}$. As the percentage of silt and clay in banks and channel increases, the shape of stream channels expressed as a width-depth ratio $(F)$ varies according to the equation, $F=255 M^{-1.08}$ Neither mean annual discharge nor the mean annual flood significantly affects this relation in spite of the importance of discharge to the absolute width and depth of a channel.

Downstream changes in width and depth of a stream channel are greatly influenced by sediment type. As $M$ increases downstream along a given river, the depth increases more rapidly and the width less rapidly with discharge than if $M$ was constant, and width-depth ratio decreases. Conversely, as $M$ decreases downstream the depth increases less rapidly and the width more rapidly with discharge than if $M$ was constant, and width-depth ratio increases. The downstream changes in width, depth and width-depth ratio along the Smoky Hill-Kansas River system is presented as an example of the importance of sediment type to stream regimen.

Unstable channels may be recognized by changes in widthdepth ratio. In general, aggrading channels have a higher widthdepth ratio than indicated by $M$; whereas degrading channels have a lower width-depth ratio than indicated by $M$.
\end{abstract}

\section{INTRODUCTION}

Lack of a simple quantitative expression of the physical properties of alluvium has hindered study of hydraulics and morphology of streams. In most studies of rivers and canals the median grain size $\left(D_{50}\right)$ has been used as the one parameter most descriptive of sediment type. However, even although of the same median grain size, sediment samples can vary widely in composition, depending on the sorting of the sample. If well sorted, the sample may consist of one type of material, such as sand; but if poorly sorted, a sample may be composed of several types, such as silt, sand, and gravel.

Studies of the behavior of sediment grains under different physical environments reveal that there is a great change in sediment character within the range 0.05 to $1.0 \mathrm{~mm}$. For example, Hjulstrom's (1935) compilation of data, concerning the critical velocity of water required to initiate movement of sediment grains of uniform material, shows that the critical velocity increases as grain size decreases below $0.1 \mathrm{~mm}$ and increases also with grain size above $0.5 \mathrm{~mm}$. According to Hjulstrom (1935, fig. 18), the velocity required to move a particle $0.02 \mathrm{~mm}$ in diameter is about the same as that required to move a grain $2.0 \mathrm{~mm}$ in diameter. Bagnold (1954, p. 88, fig. 28) indicates that a similar relation exists between the threshold velocity of wind and grain size for windblown sand, although the zone of minimum velocity exists only for a range of about 0.07 to $0.1 \mathrm{~mm}$. In addition, Rubey's (1933, p. 339, fig. 1) study of settling velocities of sediment shows that between 0.06 and 1.0 $\mathrm{mm}$ there is a transition zone between the viscous resistance formula (Stokes Law) and the impact-of-water formula. His analysis suggests that in being transported by water there is a fundamental difference in the behavior of sediment grains smaller than $0.05 \mathrm{~mm}$ from those larger than $1.0 \mathrm{~mm}$.

It is the purpose of the present study to discuss the effect of one variable, sediment character, on the shape of alluvial stream channels. It is a simplification to relate any one aspect of stream morphology to one other variable, but this may be proper as long as both the writer and reader are aware that other factors may be important and that their importance may be identified as additional information becomes available.

Valuable information on the hydrology of rivers in Kansas was provided by E. R. Leeson. F. F. Zdenek made grain-size analyses for the many sediment samples and calculated the values for mean annual flood and mean annual discharge for rivers other than those in Kansas. The writer also wishes to acknowledge the suggestions for improvement of the manuscript made by the following: W. M. Borland, Elliott Flaxman, C. R. Miller, and M. G. Wolman.

\section{SELECTION OF A PARAMETER REPRESENTATIVE OF SEDIMENT TYPE}

To obtain a valid expression of sediment type perhaps some grain-size parameter within the critical range 0.05 to $1.0 \mathrm{~mm}$ might be selected which would be more descriptive of sediment properties than median grain size alone. For example, Burmister (1952) has 
prepared tables from which one may estimate the permeability and drainage characteristics of a soil from the grain size below which 10 percent of the sample is finer (Hazen's effective size, $D_{10}$ ). Other investigators have shown that the susceptibility of soils to erosion (Bouyoucos, 1935) and the strength of cohesive soils (Trask, 1959) are related to a sand-clay ratio.

In this study the percentage of silt and clay (taken as that part of each sample passing a 200-mesh sieve, and equivalent to sediment grains smaller than 0.074 $\mathrm{mm}$ ) was selected for comparison with stream-channel characteristics. This selection avoids the use of an absolute value for grain size, the importance of which can be masked by sorting of the sample. In addition, the value can be readily obtained from the cumulative grain-size curve.

Burmister (1952, p. 20) gives some physical reasons for the selection of the 200-mesh sieve as the boundary between silt-clay and sand. He states that the soil becomes less well drained and that capillarity increases with increase in material passing the 200-mesh sieve; in addition, the 200-mesh sieve is the practical lower limit of sieving for grain-size analyses. Any grain size between $0.05 \mathrm{~mm}$ and perhaps $0.1 \mathrm{~mm}$ could be used as the boundary between silt-clay and sand; however, it is convenient to use either the 200 -mesh $(0.074 \mathrm{~mm})$ or 230-mesh $(0.0625 \mathrm{~mm})$ sieves, and the 200-mesh sieve was selected for use here.

If, as suggested above, sediment less than $0.074 \mathrm{~mm}$ greatly influences the physical properties of sediment, then this fine fraction of the sample may be considered as the matrix in which the remainder of the sediment is fixed. The data available show that, in general, $D_{10}$ decreases as percentage of silt and clay increases. Burmister's work (1952) indicates that a smaller value of $D_{10}$ is associated with lower permeability and higher cohesion, supporting the suggestion that this fraction of the sediment is most effective in increasing the resistance of alluvium to erosion.

\section{METHODS OF INVESTIGATION}

Assuming that the shape of a stream channel depends on the resistance of sediment composing the perimeter of the channel and the erosion potential of stream discharge, then sampling of bank and channel sediment at stable channel cross sections is necessary. Data were assembled for 90 cross sections, most of which were at or near Geological Survey gaging stations. Generally the gaging stations are located at stable reaches of the river. However, they often are located at bridges which might be assumed to affect the shape of the cross section. In such situations, wherever practical, the samples were collected some distance upstream or downstream from the bridge. Sometimes, however, the depth of water necessitated obtaining samples and water depth from the bridge by using a small clam-shell type dredge.

At most sections only the width and depth of the channel were measured. At others a survey was made of the channel cross section. The measurement of width and depth was to some extent subjective. Depth was measured to the lowest part of the channel from the edge of the first surface or bank above the channel floor. It is, therefore, a maximum depth. Width was measured from the edge of this bank to the corresponding elevation on the opposite side of the channel. In general, the upper limit of the measured depth could be selected not only as the edge of a terrace or bank but also as the lower edge of permanent vegetation and the upper limit of fairly recent deposition or erosion along the sides of the channel.

The gradient of the channel at the cross sections was measured with a hand level for many locations. For others, the gradient was measured on large scale topographic maps.

Composite sediment samples were taken from the channel floor and both banks. In general, the surface inch of the channel and banks was sampled along the selected cross sections; however, when the clam-shell dredge was used the samples often included a depth as much as 4 inches of channel material. Depending on channel width, samples of channel sediment were taken from 10 to 20 points across the stream.

In the laboratory the samples were subjected to a standard grain-size analysis. The samples were first sieved and if they contained more than 20 percent siltclay were then prepared for hydrometer analysis. One important deviation from the usual procedure was made to aid in the dispersion of the samples (I. S. McQueen and R. F. Miller, oral communication). Fifty grams of the sediment was placed in 700 to 800 $\mathrm{ml}$ of distilled water and allowed to stand overnight. The liquid was then decanted, removing most of the salts that might prevent total dispersion of the sample by sodium hexametaphosphate. The percentages of silt and clay in bank and channel samples, as well as the median-grain size, were taken from the plotted cumulative grain-size curves of each sample.

The sediment composing the perimeter of each channel is expressed as a weighted mean percent siltclay, designated $M$, which is calculated as follows:

$$
M=\frac{S c \times W+S b \times 2 D}{W+2 D}
$$

in which $S e$ is percentage of silt and clay in channel alluvium, $S b$ is percentage of silt and clay in bank alluvium, $D$ is channel depth, $W$ is channel width. 
Calculations of the width-depth ratio and $M$ were made by slide rule and are presented in table 1 with other data on the cross sections and sediment. Data were collected at 90 cross sections, but it was later discovered that the channels were unstable at some of these cross sections. Data from 10 unstable channels were segregated from those for the stable channels because of: (a) channel aggradation (4 sections), (b) scour below a dam or a concrete ford (2), (c) bedrock exposed in the channel (2), (d) bridge construction upstream (1), and (e) backwater effects (1 section; see table 1 , cross sections $81-90$ ).

In addition, 11 other cross sections are segregated from the 69 stable sections listed in table 1, for these channels contain a high percentage of gravel, cobbles, and even boulders (table 1, cross sections 70-80). Therefore, unless otherwise stated this study is concerned primarily with channels formed in alluvium containing only small amounts of gravel and cobbles. The 11 cross sections containing the coarser sediment and the 10 unstable sections will be discussed separately.

Mean annual flood (recurrence interval 2.33 years) and mean annual discharge were obtained from data published in Geological Survey water-supply papers and unpublished reports for those sections at or near gaging stations.

TABLE 1.-Channel and sediment data

[Location numbers in parentheses for cross sections 1-14 are author's original cross-section numbers]

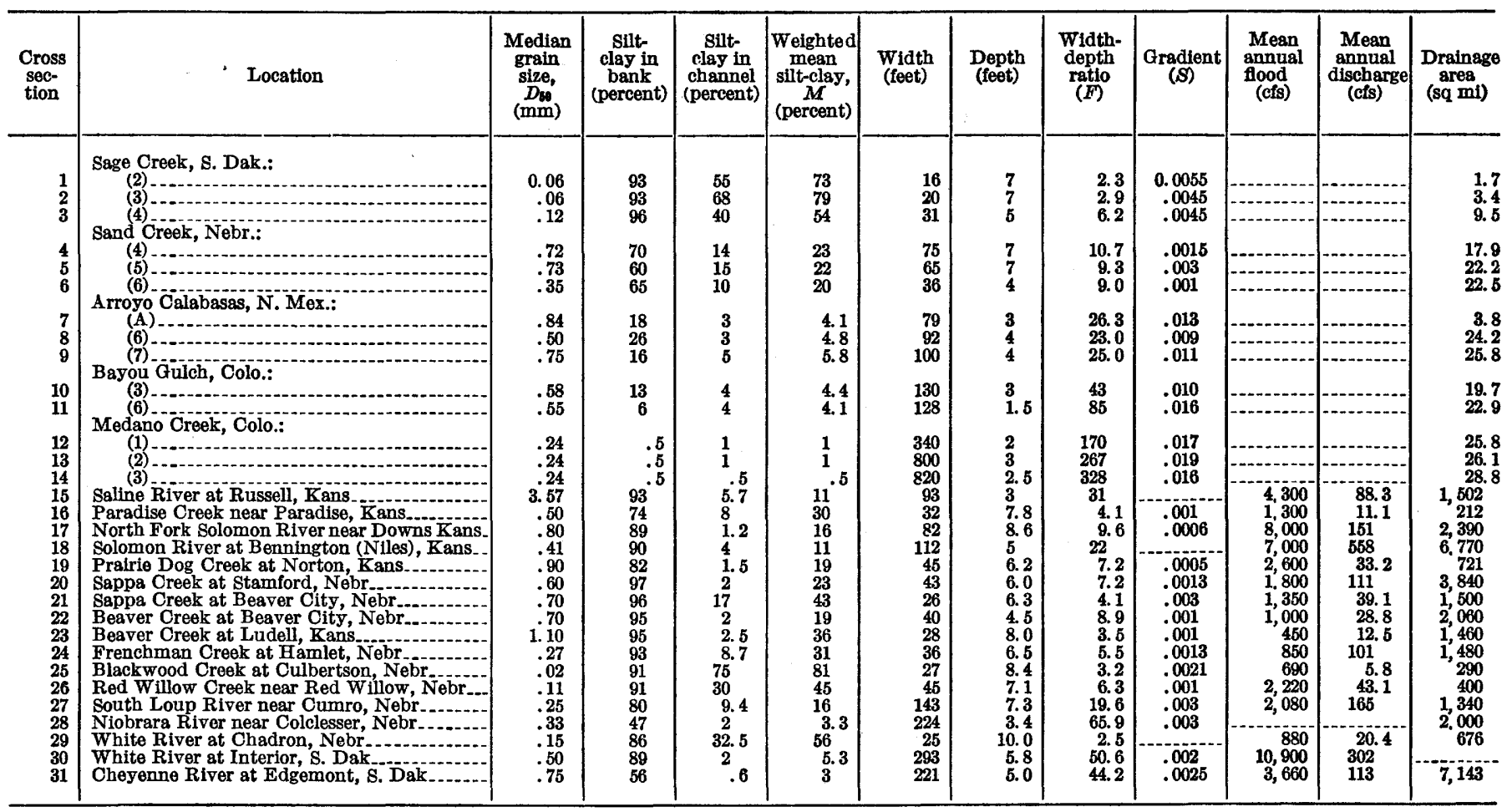

Smoky Hill-Kansas Rivers systen

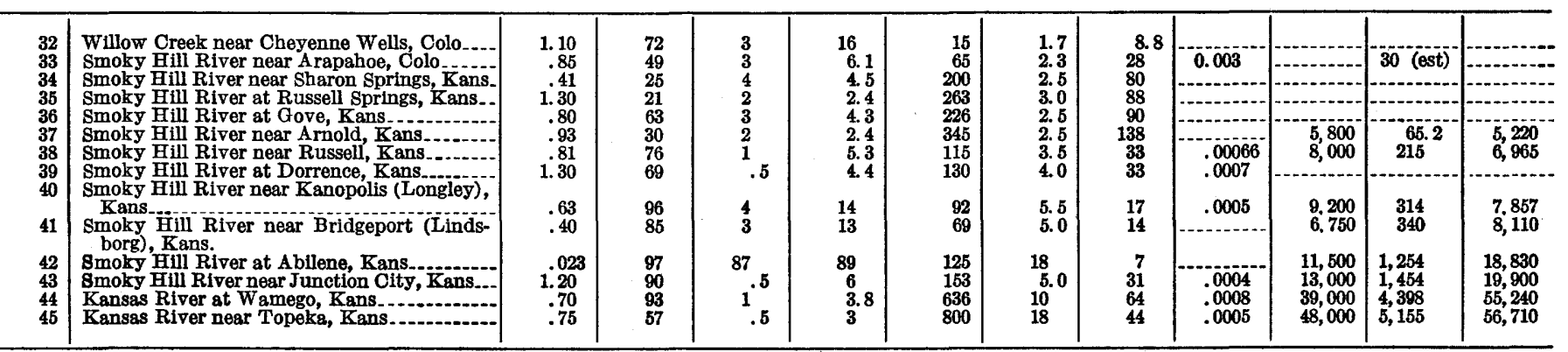


TABLE 1.-Channel and sediment data-Continued

[Location numbers in parentheses for cross sections 1-14 are author's original eross-section numbers]

\begin{tabular}{|c|c|c|c|c|c|c|c|c|c|c|c|c|}
\hline $\begin{array}{l}\text { Cross } \\
\text { sec- } \\
\text { tion }\end{array}$ & Location & $\begin{array}{c}\text { Median } \\
\text { grain } \\
\text { size, } \\
D_{10} \\
(\mathrm{~mm})\end{array}$ & $\begin{array}{c}\text { Silt- } \\
\text { elay in } \\
\text { bank } \\
\text { (percent) }\end{array}$ & $\begin{array}{l}\text { Silt- } \\
\text { clay in } \\
\text { channel } \\
\text { (percent) }\end{array}$ & $\begin{array}{l}\text { Weighted } \\
\text { mean } \\
\text { silt-clay, } \\
\boldsymbol{M} \\
\text { (percent) }\end{array}$ & $\begin{array}{l}\text { Width } \\
\text { (feet) }\end{array}$ & $\begin{array}{c}\text { Depth } \\
\text { (feet) }\end{array}$ & $\begin{array}{l}\text { Width- } \\
\text { depth } \\
\text { ratio } \\
(F)\end{array}$ & $\begin{array}{l}\text { Gradient } \\
(S)\end{array}$ & $\begin{array}{c}\text { Mean } \\
\text { annual } \\
\text { food } \\
\text { (cfs) }\end{array}$ & $\begin{array}{c}\text { Mean } \\
\text { annual } \\
\text { discharge } \\
\text { (cfs) }\end{array}$ & $\begin{array}{l}\text { Drainage } \\
\text { area } \\
\text { (sq mi) }\end{array}$ \\
\hline
\end{tabular}

\begin{tabular}{|c|c|c|c|c|c|c|c|c|c|c|c|c|}
\hline \multicolumn{13}{|c|}{ Republican River system } \\
\hline & Arikaree River near Arikaree, Colo & \multirow{3}{*}{$\begin{array}{r}1.10 \\
.25 \\
.38 \\
.48\end{array}$} & \multirow{3}{*}{$\begin{array}{l}82 \\
65 \\
31 \\
44\end{array}$} & \multirow{3}{*}{$\begin{array}{l}\mathbf{3} \\
\mathbf{3} \\
\mathbf{3} \\
\mathbf{1 . 5}\end{array}$} & \multirow{3}{*}{$\begin{array}{l}4.7 \\
8.7 \\
3.4 \\
3.4\end{array}$} & \multirow{3}{*}{$\begin{array}{r}206 \\
68 \\
400 \\
100\end{array}$} & \multirow{3}{*}{$\begin{array}{l}2.2 \\
3.0 \\
3.0 \\
2.3\end{array}$} & \multirow{3}{*}{$\begin{array}{r}94 \\
23 \\
133 \\
43\end{array}$} & & & & \multirow{5}{*}{$\begin{array}{r}1,60 \\
2,580 \\
4,770 \\
5,760 \\
22,400\end{array}$} \\
\hline $\begin{array}{l}47 \\
48\end{array}$ & $\begin{array}{l}\text { Arikaree River at Haigler, Nebr } \\
\text { Republican River near Stratton, Nebr...... }\end{array}$ & & & & & & & & 0.002 & 3,500 & 19.6 & \\
\hline 49 & South Fork Republican River near Benkie- & & & & & & & & .002 & 4,500 & (56.8 & \\
\hline 50 & Republican River near Benkleman, Nebr & .25 & 23 & 6 & 6.7 & 123 & 2.5 & 49 & .003 & 2,175 & 105 & \\
\hline 52 & $\begin{array}{l}\text { Republican River near Bostwick (Hardy), } \\
\text { Nebr. }\end{array}$ & .63 & 29 & 1.0 & $\begin{array}{l}7.8 \\
2.8\end{array}$ & 154 & 5.0 & 31 & .000 & 12,000 & 843 & \\
\hline $\begin{array}{l}53 \\
54\end{array}$ & $\begin{array}{l}\text { Republican River at Concordia, Kans........ } \\
\text { Republican River at Junction City, Kans... }\end{array}$ & .70 & $\begin{array}{l}34 \\
59\end{array}$ &.$^{2}$ & $\begin{array}{l}1.4 \\
3.4\end{array}$ & $\begin{array}{l}250 \\
300\end{array}$ & $\begin{array}{l}5.0 \\
6.5\end{array}$ & $\begin{array}{l}50 \\
46\end{array}$ & .0007 & $\begin{array}{l}13,000 \\
15,000\end{array}$ & 1,000 & $\begin{array}{l}23,540 \\
24,900\end{array}$ \\
\hline
\end{tabular}

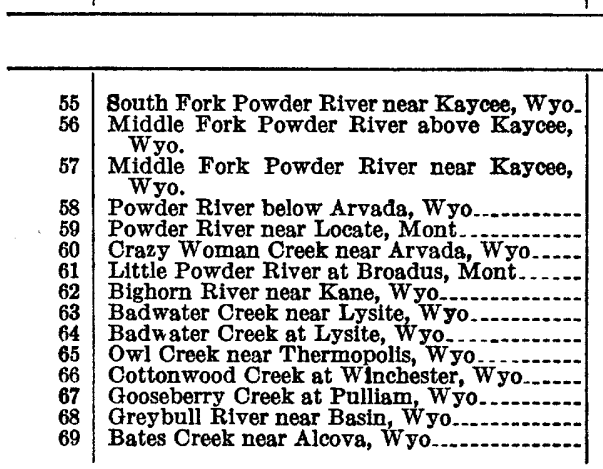

Powder River system

\begin{tabular}{|c|c|c|c|c|c|c|c|c|c|c|}
\hline $\begin{array}{r}0.63 \\
22.0\end{array}$ & $\begin{array}{l}71 \\
60\end{array}$ & $\begin{array}{r}9 \\
14\end{array}$ & ${ }_{20}^{11.3}$ & $\begin{array}{r}119 \\
35\end{array}$ & $\begin{array}{l}2.3 \\
2.5\end{array}$ & $\begin{array}{l}52 \\
14\end{array}$ & $\begin{array}{r}0.004 \\
.005\end{array}$ & $\begin{array}{r}3,900 \\
574\end{array}$ & $\begin{array}{l}35 \\
58\end{array}$ & $\begin{array}{r}1,150 \\
450\end{array}$ \\
\hline .40 & 69 & 15 & 23 & 47 & 4.4 & 11 & .0015 & 1,630 & 133 & 980 \\
\hline \multirow{6}{*}{$\begin{array}{c}.21 \\
.42 \\
.50 \\
4.10 \\
.16 \\
.43 \\
.24 \\
.21 \\
1.0 \\
8.0 \\
.50 \\
.90\end{array}$} & \multirow{6}{*}{$\begin{array}{l}70 \\
58 \\
75 \\
82 \\
35 \\
47 \\
58 \\
69 \\
15 \\
45 \\
72 \\
63\end{array}$} & \multirow{6}{*}{$\begin{array}{c}4 \\
13 \\
2 \\
5.5 \\
20 \\
3 \\
5 \\
2 \\
8 \\
2.5 \\
7 \\
14\end{array}$} & \multirow{6}{*}{$\begin{array}{c}6.5 \\
15 \\
17 \\
22 \\
21 \\
6.7 \\
7.3 \\
14 \\
8.4 \\
5.7 \\
9.9 \\
18\end{array}$} & \multirow{6}{*}{$\begin{array}{r}175 \\
234 \\
33 \\
40 \\
220 \\
50 \\
109 \\
35 \\
133 \\
59 \\
134 \\
69\end{array}$} & \multirow{6}{*}{$\begin{array}{l}3.5 \\
4.5 \\
4.4 \\
5.5 \\
8.5 \\
2.3 \\
2.5 \\
3.9 \\
3.5 \\
2.4 \\
3.1 \\
2.8\end{array}$} & \multirow{6}{*}{$\begin{array}{l}50 \\
52 \\
7.5 \\
7.3 \\
26 \\
22 \\
44 \\
9.0 \\
38 \\
25 \\
43 \\
25\end{array}$} & .0011 & \multirow{3}{*}{$\begin{array}{r}9,400 \\
1,150 \\
1,280 \\
16,100\end{array}$} & \multirow{3}{*}{$\begin{array}{r}639 \\
40 \\
39 \\
2,888\end{array}$} & \\
\hline & & & & & & & 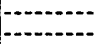 & & & 956 \\
\hline & & & & & & & $0-37$ & & & 15,000 \\
\hline & & & & & & & $\begin{array}{l}.0037 \\
.0015\end{array}$ & 685 & 34 & 484 \\
\hline & & & & & & & .006 & 311 & 10 & 371 \\
\hline & & & & & & & $\begin{array}{l}.0015 \\
.0035\end{array}$ & $\begin{array}{r}3,140 \\
500\end{array}$ & $\begin{array}{r}178 \\
16\end{array}$ & $\begin{array}{r}1,130 \\
377\end{array}$ \\
\hline
\end{tabular}

Gravel streams eliminated 1

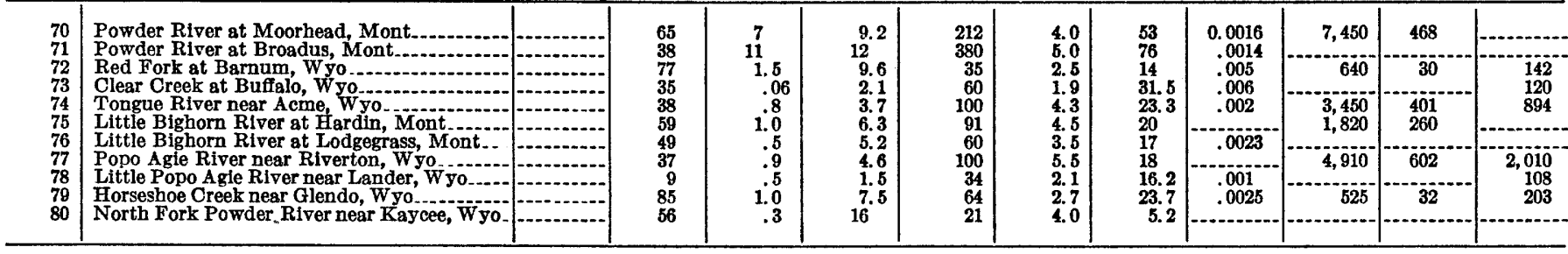

Miscellaneous sections eliminated 1

\begin{tabular}{|c|c|c|c|c|c|c|c|c|c|c|c|c|}
\hline \multirow{5}{*}{$\begin{array}{l}81 \\
82 \\
83 \\
84 \\
85 \\
86 \\
87 \\
88 \\
89 \\
90\end{array}$} & \multirow{5}{*}{ 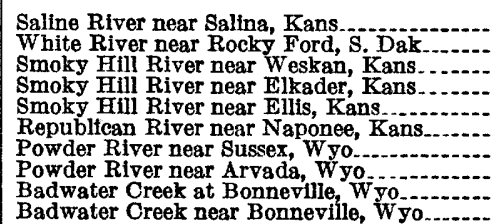 } & \multirow{5}{*}{$\begin{array}{l}0.013 \\
1.10 \\
.70 \\
1.20 \\
.72 \\
.62 \\
.07 \\
.15 \\
.17 \\
.37\end{array}$} & \multirow{5}{*}{$\begin{array}{l}92 \\
88 \\
14 \\
55 \\
18 \\
47 \\
64 \\
78 \\
32 \\
21\end{array}$} & \multirow{5}{*}{$\begin{array}{l}91 \\
1.2 \\
3 \\
4 \\
.5 \\
51.5 \\
32 \\
7 \\
7\end{array}$} & \multirow{5}{*}{$\begin{array}{c}91 \\
5.1 \\
6.3 \\
4.8 \\
1.9 \\
3.6 \\
52 \\
34 \\
7.5 \\
7.3\end{array}$} & \multirow{5}{*}{$\begin{array}{r}56 \\
170 \\
36 \\
500 \\
72 \\
127 \\
177 \\
170 \\
291 \\
224\end{array}$} & \multirow{5}{*}{$\begin{array}{l}10 \\
4 \\
3 \\
4 \\
3 \\
4.5 \\
3.7 \\
4.5 \\
3 \\
2.5\end{array}$} & \multirow{5}{*}{$\begin{array}{l}5.6 \\
42.5 \\
12 \\
125 \\
24 \\
28 \\
48 \\
38 \\
97 \\
89.5\end{array}$} & & & & \\
\hline & & & & & & & & & 0.006 & 3,000 & 32.1 & 3,560 \\
\hline & & & & & & & & & .0007 & $\begin{array}{r}6,500 \\
11,350\end{array}$ & $\begin{array}{l}97.7 \\
72 B\end{array}$ & \\
\hline & & & & & & & & & $\begin{array}{l}.0008 \\
.0007\end{array}$ & $\begin{array}{l}5,850 \\
8,600\end{array}$ & $\begin{array}{l}151 \\
382\end{array}$ & $\begin{array}{l}3,090 \\
6,050\end{array}$ \\
\hline & & & & & & & & & & 1,280 & & \\
\hline
\end{tabular}

1 Sections not plotted on figure 8.

\section{CHANNEL SHAPE AND SEDIMENT TYPE}

The shape of each cross section expressed as a dimensionless width-depth ratio is plotted against $M$ in figure 8 for 69 cross sections (table 1). The correlation between channel shape and sediment is such that

$$
F=255 M^{-1.08}
$$

where $F$ is the channel shape expressed as a widthdepth ratio and $M$ is the weighted mean percent siltclay. Neither the percentage of silt and clay in the banks nor in the channel alone show a correlation with width-depth ratio.
The wide range of channel shapes represented on figure 8 suggests that for alluvial channels in which pebbles and gravel cover only negligible parts of the channel, the shape of the channel is dependent on sediment type expressed as $M$. It is interesting to note that for those sections near gaging stations, the mean annual discharge ranged from 20 to $5,150 \mathrm{cfs}$ (cubic feet per second). In addition, many of the streams are ephemeral, in contrast to the perennial flow of the Smoky Hill, Kansas, and Republican Rivers. Drainage area ranges from about 1.7 square miles for the smallest ephemeral stream to 56,710 square miles for the Kansas River at Topeka. In spite of the wide range in stream 


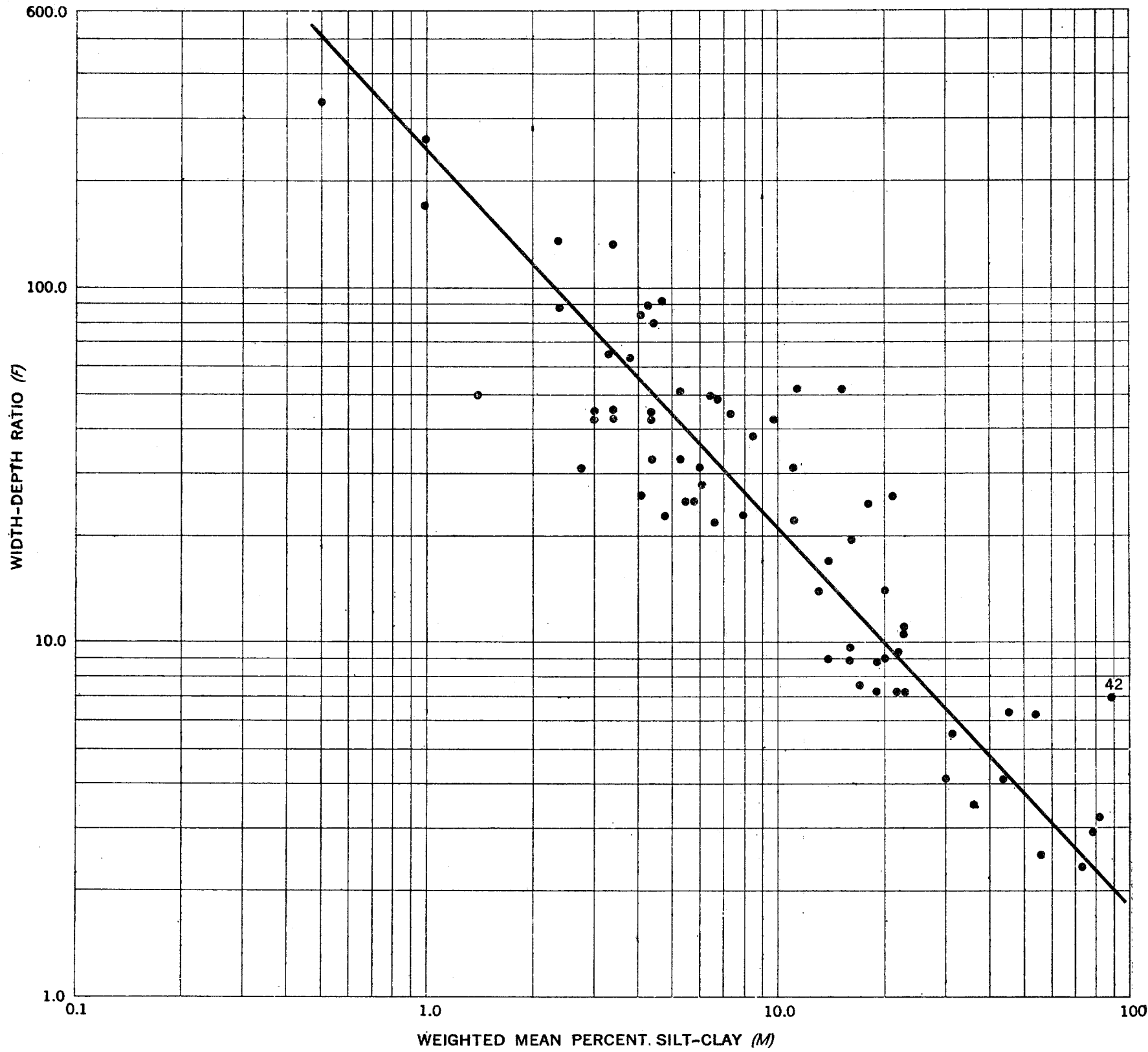

FIGURE 8-Relation between width-depth ratio and weighted mean percent silt-clay at different cross sections. The regression line was determined graphically. Standard error is $0.202 \mathrm{log}$ units, and correlation coefficient is 0.91. Point 42 is for Smoky Hill River at Abllene, Kans.

regimen and sediment type, the correlation coefficient for the regression line is 0.91 . The variety of stream types represented are illustrated in plate $5 A-F$.

The correlation of figure 8 shows that channels containing little silt-clay are relatively wide and shallow; whereas those composed predominantly of silt-clay are relatively narrow and deep. The correlation seems to justify the selection of $M$ as a parameter descriptive of sediment characteristics. A plot of the median grain size against percentage of silt and clay in the channel samples shows no correlation, indicating that median grain size has no relation to channel shape for the range of channels investigated.

$588578-61-2$
The scatter of points on figure 8, although not excessive, may be partly explained on the basis of normal stream variability. Note that the scatter of points appears greater where $M$ is less than 25 , if point 42 is disregarded. Sandy streams are generally unstable in that they may scour or deepen their channels during floods. In any event, changes in channel elevation of 1 foot are common after a flood. Where the channels are hundreds of feet wide such a small change in depth causes a relatively large change in the width-depth ratio and thus greater scatter of the points representative of sandy channels. Point 42 on figure 8 is for the Smoky Hill River at Abilene. The introduction of 
large amounts of silt-clay into this reach of the river markedly alters its appearance (pl. $5 E$ ). This may cause point 42 to lie well above the curve, but the gaging-station records suggest little change in gage height in this reach, and it was not eliminated as were sections 81 to 90 .

Also more refined techniques might further reduce the scatter. For example, channel maximum depth might be replaced by a mean depth, obtained by dividing the area of cross section by width. Mean depth was calculated for 20 sections at which the cross-sectional area was known. Where mean depth was used to calculate width-depth ratio, the ratio increased on the average by 1.5. However, neither the slope of the regression line nor the scatter about the regression line were changed.

It is hazardous to attempt to extrapolate the relationship of figure 8 as a general law for alluvial channel shape, but it is interesting to note that Rubey's (1952) comparison of the Illinois and Mississippi Rivers reveals differences similar to those noted between the sections characterized by high $M$ and low $M$ in this study. Fisk (1944, p. 50) concluded from studies of the alluvial valley of the Mississippi River that the channel is wide and shallow where the river flows through sandy deposits and conversely is deep and narrow in the fine-grained materials of the deltaic plain. Most investigators have recognized from experience that sandy channels are wide compared with those cut in silty or clayey materials (Leopold and Maddock, 1953, p. 46).

The reason for the relation between channel shape and percentage of silt and clay (fig. 8) is found in studies made by hydraulic engineers. Lane (1937, p. 124) states, “*** the greater the width-depth ratio the greater will be the ratio of the velocity acting on the bottom to that acting on the sides of a channel." Where a narrow trench is cut in an alluvial valley, the tractive forces acting on the channel sides will be great, causing widening of the channel. Widening will continue until the resistance of the banks to scour prevents it. If the material in which the channel is cut is highly cohesive (has a high percent of silt-clay) the channel will be narrow, but if the alluvium lacks cohesion (has a small percent of silt-clay) the channel will widen to a greater extent. Canals that carry a high bedload in friable or easily eroded material require high velocities on the bed to move the load and low

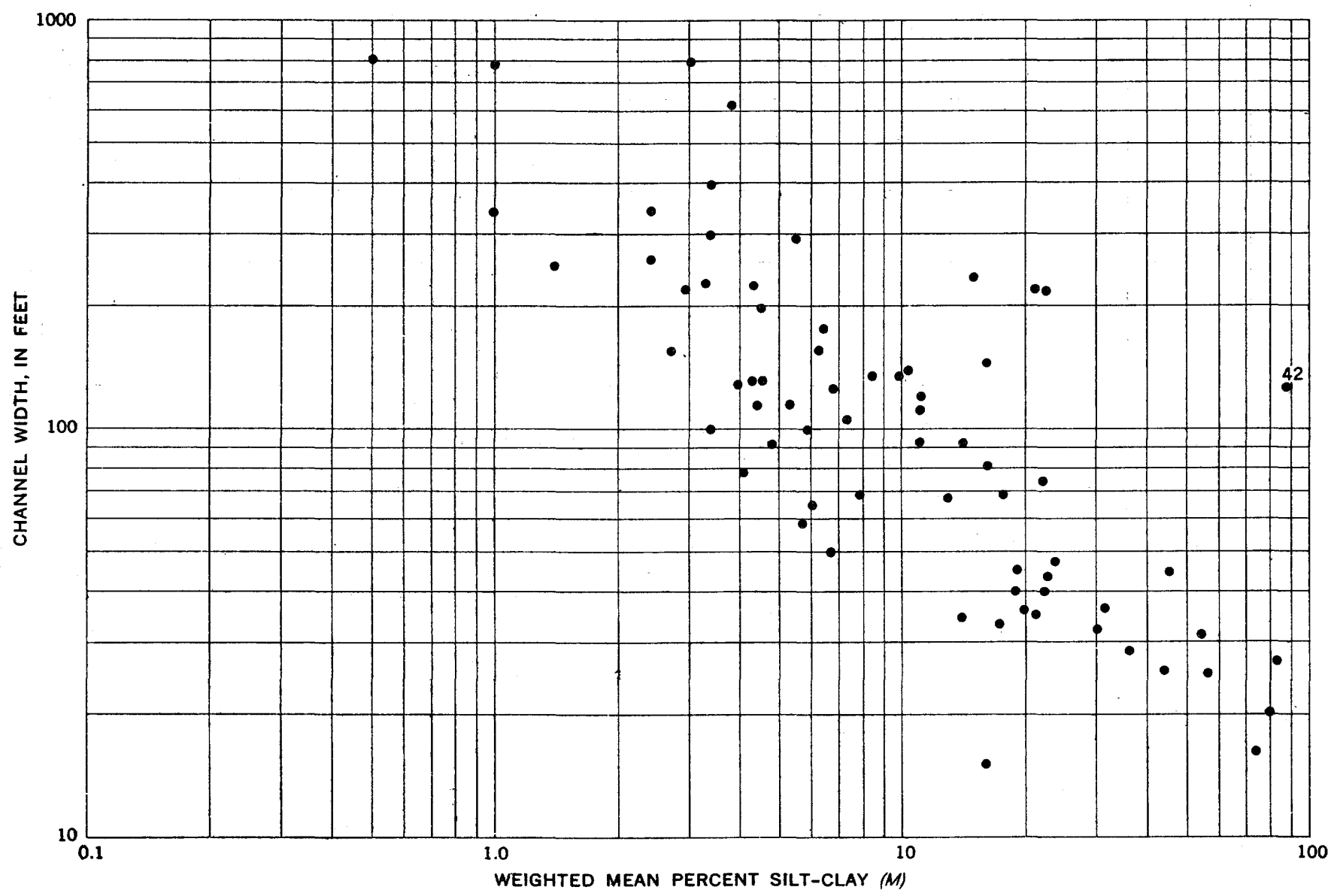

Figdre 9.-Relation between channel width and weighted mean percent silt-clay at different cross sections (M). Point 42 is for the Smoky Hill River at Abilene, Kans. 

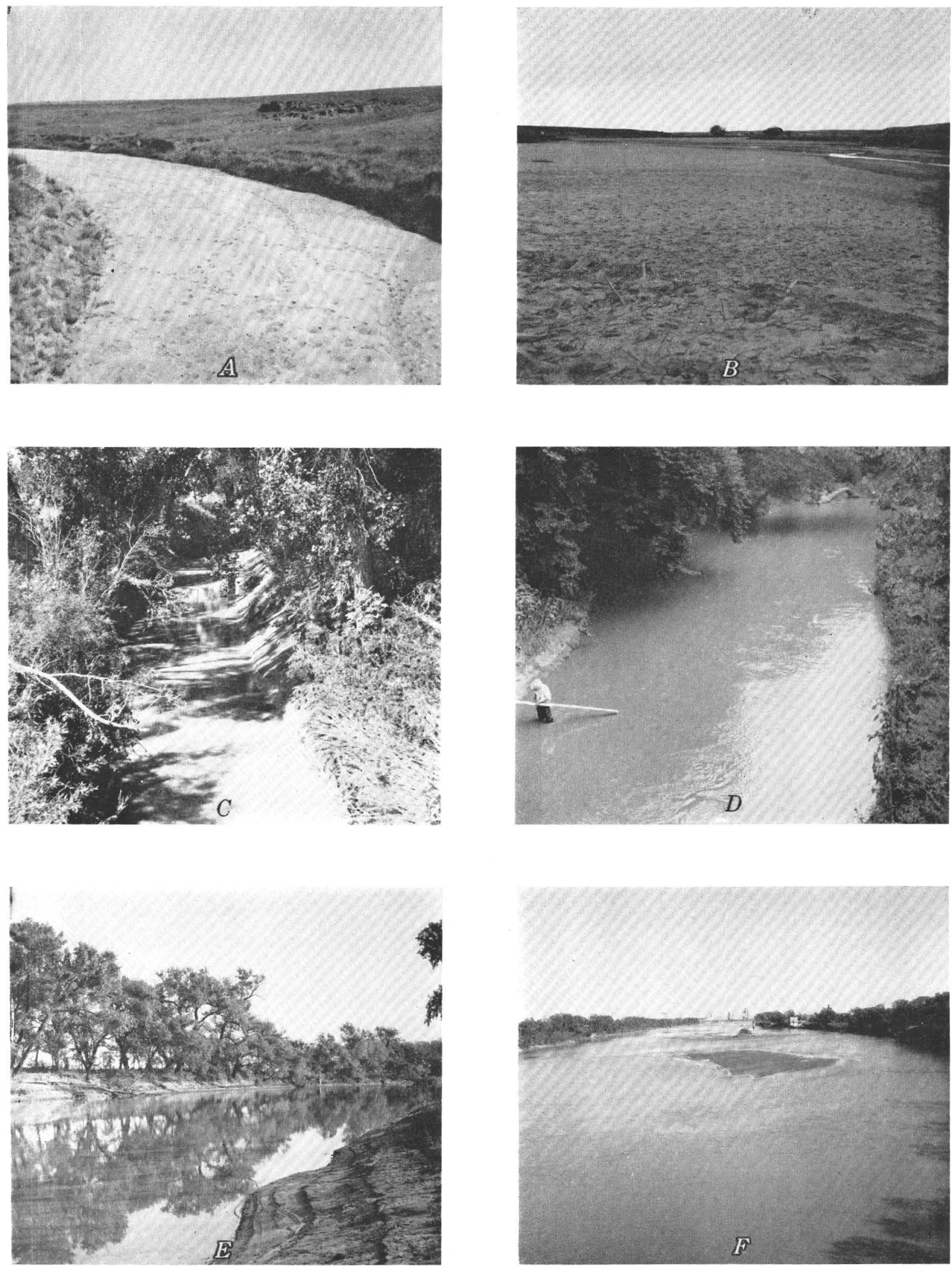

STREAM CHANNELS ILLUSTRATING RANGE OF CHANNEL CHARACTERISTICS AT MEASURED CROSS SECTIONS

$A$, Smoky Hill River near Arapahoe, Colo. (cross section 33); B, Smoky Hill River above Cedar Bluff Reservoir, Kans. (cross section 37); $C$, White River near Chadron, Nebr. (cross section 29); D, Sappa Creek at Stamford, Nebr. (cross section 20); E, Smoky Hill River near Abilene .Kans. (eross section 42); F Kansas River near Topeka, Kans, (cross section 45). 


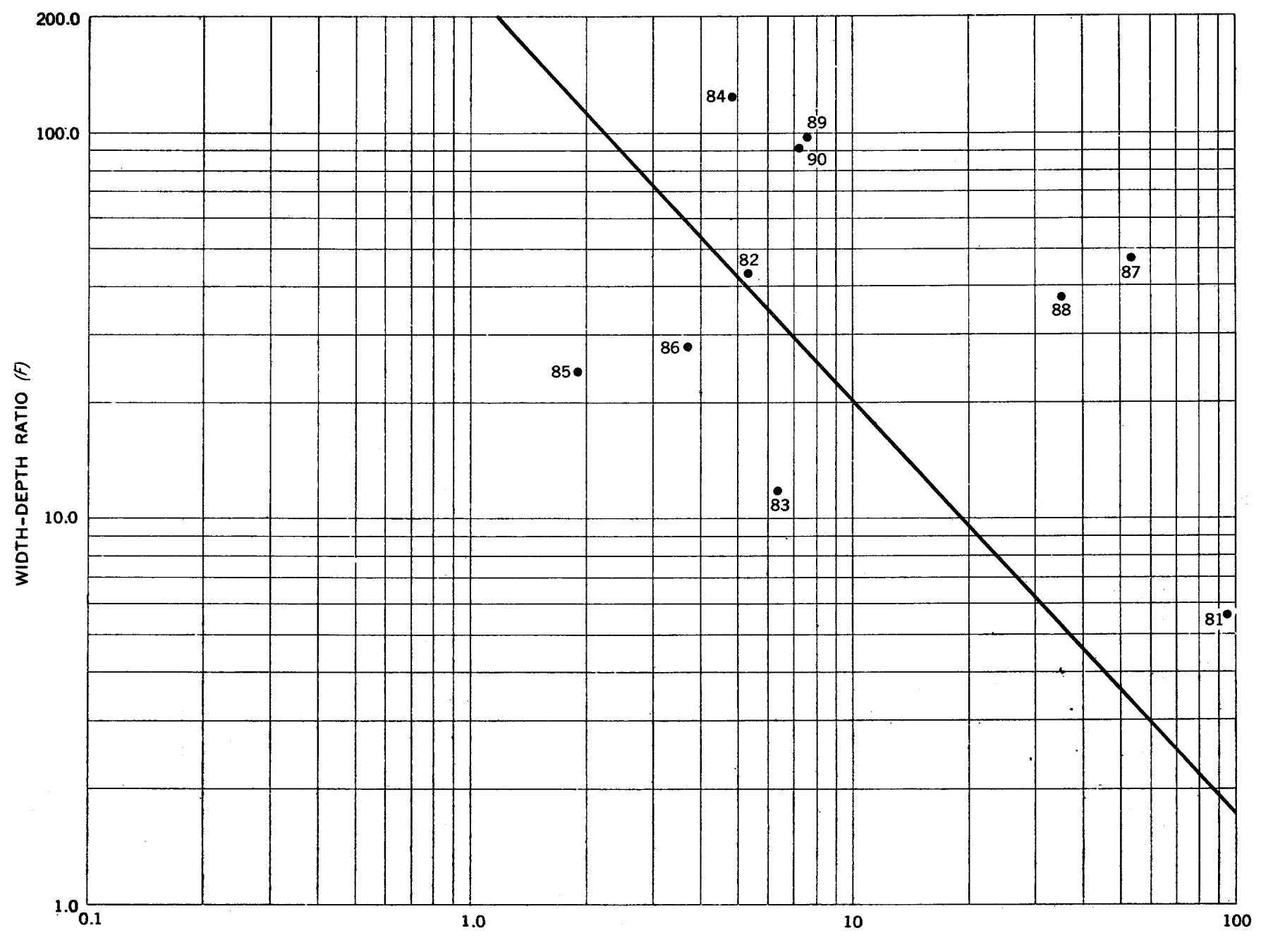

WEIGHTED MEAN PERCENT SILT-CLAY (M)

Froure 10.-Relation of width-depth ratio to weighted mean percent silt-clay $(M)$ for unstable cross sections. Numbers refer to cross sections listed in table 1. Regression line is that determined from data on figure 8.

velocities along the banks to prevent cutting them, thus a high width-depth ratio is required for a stable channel in friable material (Lane, 1937, p. 124).

It is also noteworthy that the shape of the channels seems to be independent of discharge. Plots of mean annual flood and mean discharge against width-depth ratio showed no recognizable correlation. The absolute size of the channel, the width and depth in feet, is related to mean discharge (Leopold and Maddock, 1953), but the ratio of width to depth is apparently determined by sediment type $(M)$ for the channels sampled. The data show a correlation between channel width and $M$ (fig. 9), but the scatter of points is such that the width may vary as much as 10 times for any one value of $M$. Nevertheless, the lack of correlation between channel depth and $M$, suggests that perhaps channel width is more sensitive to changes in $M$ than depth.
A discussion follows on the 21 cross sections eliminated because of instability or the presence of excess coarse sediment on the channel floor.

In figure 10 the width-depth ratio is plotted against $M$ for the 10 cross sections eliminated from prior discussion. The regression line of figure $8 \mathrm{has}$ been drawn on figure 10 to show where the 10 points lie in relation to the regression line for stable channels. The two cross sections which show scour either downstream from a dam (85) or downstream from a concrete ford (83) lie far below the regression line. The two cross sections in which bedrock was exposed $(82,86)$ lie close to the regression line; whereas, those in which the rating curves of gage height to discharge show a progressive increase in gage height with constant discharge, suggesting aggradation, (84, 88, 89, 90) lie above the curve. The location of point 81 is probably the result of recorded backwater effects due to floods on the Smoky Hill River, 


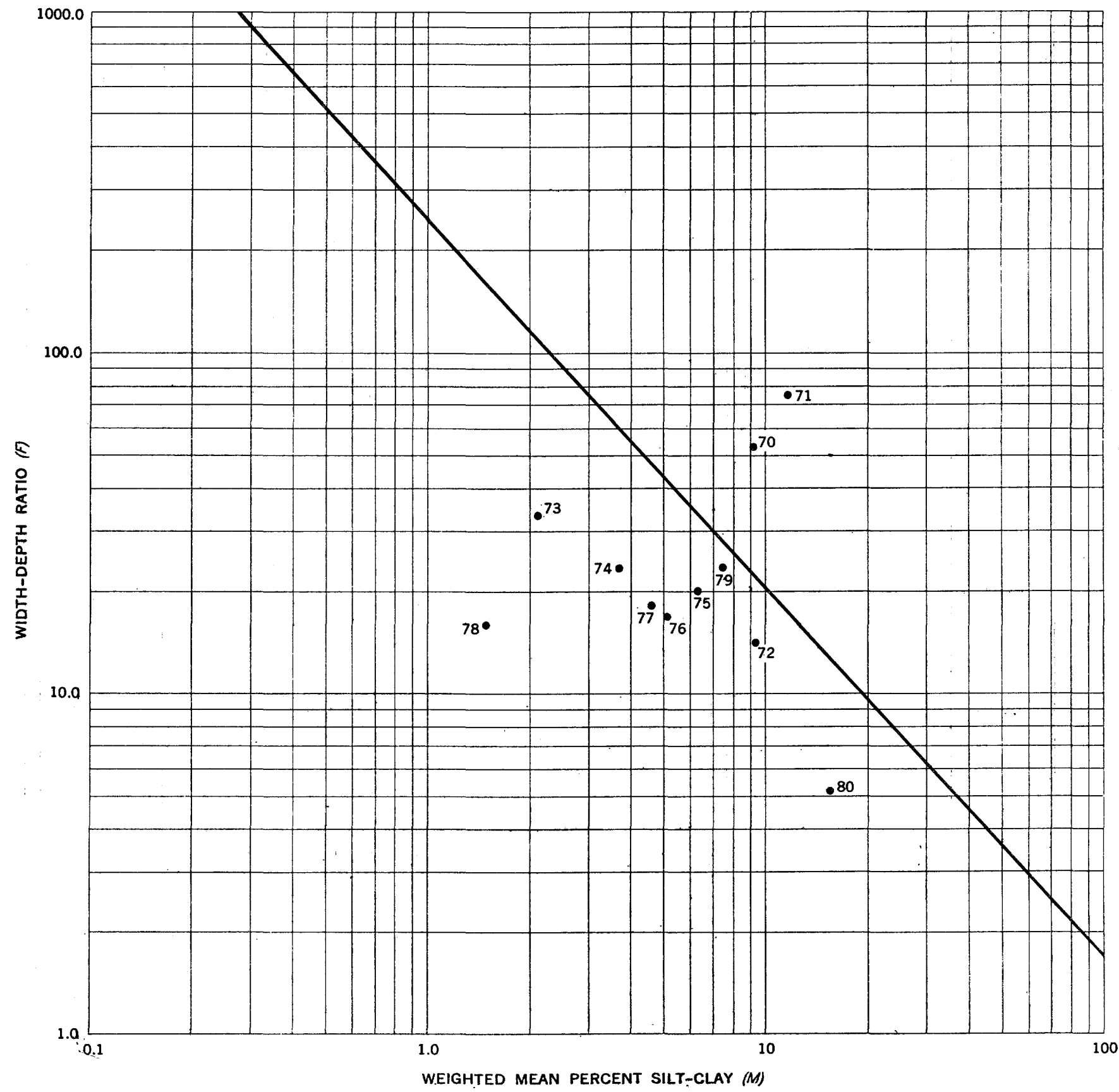

FiGURE 11.-Relation between width-depth ratio and weighted mean percent silt-elay $(M)$ for cross sections with the channel floor covered by more than 40 percent gravel, cobbles, and boulders. Numbers refer to cross sections listed in table 1. Regression line is that determined from data on figure 8.

The last point (87) lies above the regression line. This is attributed to bridge construction upstream which has caused a veneer of fine sediment to be deposited over the coarser material characteristic of this section.

The relation of these points to the regression line suggests that the regression line of figure 8 may be used as a criterion of channel stability. Aggrading sections will have a larger width-depth ratio than expected on the basis of $M$; whereas degrading channels will have smaller width-depth ratios than expected on the basis of $M$ alone.
Possibly the line of figure 8 is a true regression line. The channel cross sections which plot above the line, because they are aggrading or have been aggraded, may be expected to regress toward a stable form by erosion; whereas channel cross sections which plot below the line, because they are degrading or have been degraded, may be expected to regress toward a stable form by a combination of bank erosion and aggradation.

The other cross sections not plotted in figure 8 are those with appreciable gravel along the perimeter of the channel cross section. All of these sections have 


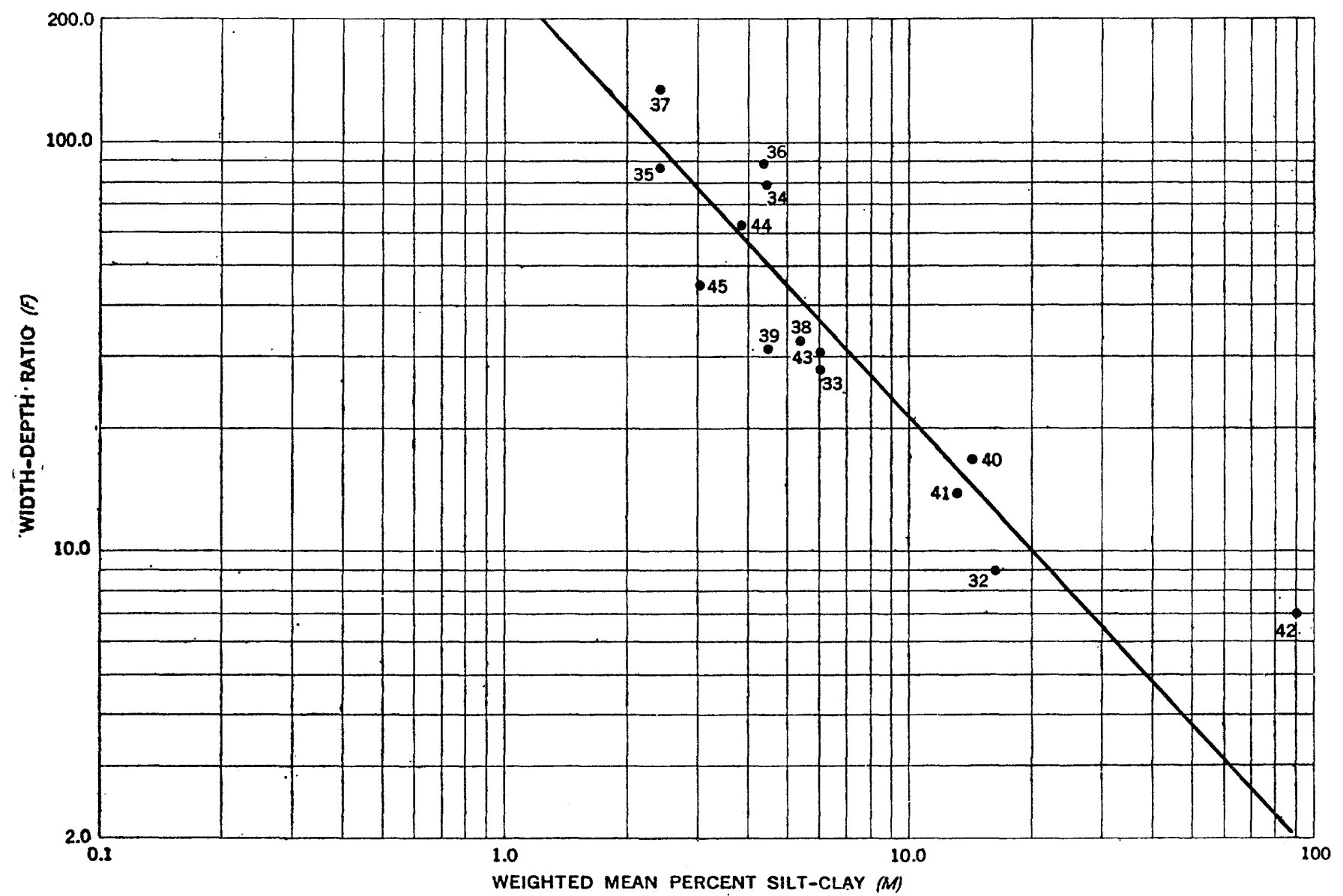

FrGURe 12.-Relation of width-depth ratio to $M$ along the Smoky Hill-Kansas River. Regression line is that determined by data on flgure 8 . Numbers refer to cross sections listed in table 1.

greater than 40 percent of the channel floor covered by coarse sediment. Data from these cross sections are plotted on figure 11. Only three points lie far from the regression line. The remaining eight points fall reasonably close to but below the regression line. The reason for this is not clear for it was expected that a gravel or cobble veneer would prevent bottom scour and result in a higher width-depth ratio.

However, data compiled on the width and depth of irrigation canals ${ }^{1}$ show that channels and banks containing coarse noncohesive materials are protected by the larger sizes of alluvium. Therefore, the widthdepth ratio of channels containing gravel and cobbles should be relatively low as seen on figure 11 .

\section{EFFECT OF SEDIMENT TYPE ON DOWNSTREAM VARIATIONS IN CHANNEL SHAPE}

This discussion has been concerned solely with data from a great variety of streams. Most studies of fluvial morphology and regime canals deal with the relations between discharge and channel dimensions along a

\footnotetext{
1 Simons, D. B., 1957, Theory and design of stable channels in alluvial materials Unpub. thesis, Colorado State Univ., 394 p.
}

single river or canal. The relation shown in figure 8 suggests that the effect of $M$ on downstream changes in channel dimensions is important.

The Smoky Hill-Kansas River system is of particular interest with regard to the effect of downstream variations of $M$ to channel shape, width, and depth. To illustrate this $M$ and width-depth ratio for 14 cross sections are plotted on figure 12 .

In eastern Colorado and western Kansas the Smoky Hill River is wide, shallow, ephemeral (pl. $5 A, B$; fig. 12 , points 33 to 37 ), and $M$ is generally less than 10 . $M$ increases in central Kansas to about 12 (fig. 12, points 40 and 41); between Salina and Abilene the Saline and Solomon Rivers introduce large amounts of silt-clay into the river, and $M$ increases sharply to more than 80 (pl. $5 E$; fig. 12 , point 42). Downstream from Abilene the river becomes progressively more sandy (fig. 12, point 43 ) to the confluence with the Republican River, the beginning of Kansas River. The Republican River introduces large amounts of sand into the Kansas River, and $M$ decreases to about 3 (pl. $5 F$; fig. 12 , points 44,45 ). 


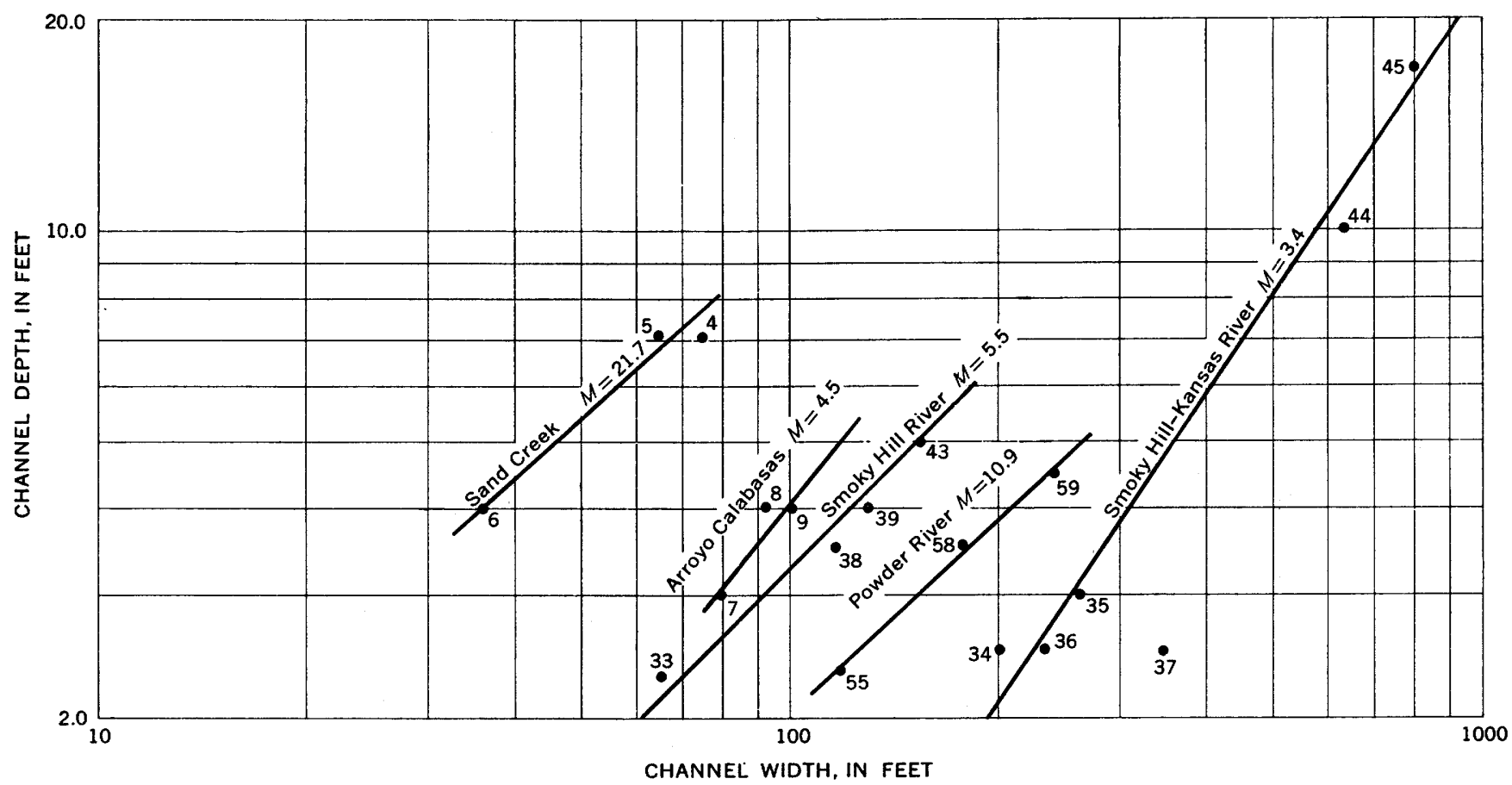

FIGUR 13.-Relation between width and depth for streams with not greatly different values of $M$ in a downstream direction. Number following name of stream is mean value of $M$ for points forming each line, and numbers beside points refer to cross sections listed in table 1.

Lacey (1930) showed that the depth and width of regime canals increase in an orderly manner with discharge and suggested that the intercept or position of the regression line of width to depth for each canal is determined by grain size. Plotting width against maximum depth for all the 69 cross sections results in an undecipherable pattern; however, when data for individual streams are plotted a group of curves results (fig. 13).

In figure 13 each regression line is drawn in relation to points representing cross sections having not greatly different values of $M$. The positions of the lines representative of ephemeral streams are apparently determined by $M$. The Sand Creek line, with a high value of $M$, lies high and to the left. The Arroyo Calabasas regression line lies lower to the right as $M$ decreases. However, mean annual discharge is also important in determining the position of the curves, for both the Smoky Hill River and Powder River curves, with a higher value of $M$, lie to the right of Arroyo Calabasas regression line. Nevertheless, the regression lines for rivers with approximately equal discharge would probably have intercepts determined by $M$.

In contrast to the straight regression lines which may be drawn through points representative of cross sections with nearly similar values of $M$, the width-depth data for the Smoky Hill-Kansas River system reveals that the variability of $M$ in a downstream direction has a marked effect on the relation of channel width to depth (fig. 14).

In a downstream direction along the Smoky Hill River, $M$ decreases from 16 to 2.4 between cross sections 32 and 37 . This change is accompanied by a relatively large increase in channel width in relation to depth. However, between cross sections 37 and $41 M$ increases from 2.4 to 13 and depth increases as channel width decreases to about one-fourth of its former value. The introduction of large quantities of silt and clay into the channel between cross sections 41 and 42 causes an abrupt increase in channel depth with a proportionally smaller increase in width. Downstream from cross section $42, M$ decreases from 89 to 6 and channel depth decreases sharply. Between cross sections 43 and 45 , $M$ decreases and width again increases more than depth.

Two large dams on the Smoky Hill River are another probable cause of some variation in the plot of figure 14 . The Cedar Bluffs Dam, completed in 1951, is located between cross sections 37 and 38. The Kanopolis Dam, completed in 1948, is located between cross sections 40 and 41.

It has been shown that the construction of a dam may cause upstream and downstream changes in channel character. For example, cross section 85, located a short distance downstream from the Cedar Bluffs Dam, was classed as an unstable channel because of recent degradation. However, in spite of the possible effects of these structures on streamflow and channel character, 
the relation between gage height and discharge for each cross section showed no progressive change which would indicate channel instability. In addition, cross sections 37 through 41 show no unusual scatter on figure 12 .

However, if it is assumed that the dams have an effect on channel width and depth, then the major portion of this effect can be eliminated by discarding cross sections 37 through 41 from figure 14. This will cause some alteration of the figure, for the second and third segments of the graph will be replaced by a line between cross sections 36 and 42 ; however, the greater part of the variability of the figure will remain to be explained by downstream variations of $M$.

Annual discharge increases progressively in a downstream direction (table 1) so the variations in channel shape are not the result of water losses. Therefore, figure 14 suggests that as $M$ changes in a downstream direction neither channel width nor depth will show a consistent relation with mean annual discharge. Depending on the change in alluvial character either width or depth may decrease in a downstream direction.

This effect of sediment type on the relation between width and mean annual discharge can be demonstrated by plotting the two variables in the manner of Leopold and Maddock (1953) for cross sections for which discharge data are available (fig. 15) along the Smoky Hill, Republican, and Kansas Rivers. It is important to remember here that width and depth as used in this study are not the same as the width and depth for mean annual discharge as used by Leopold and Maddock (1953).

The relation between mean annual discharge and channel width is almost a straight line for the Republican-Kansas River cross sections, in which $M$ ranges from 1.4 to 8 ; however, the same variables show great irregularity for the Smoky Hill-Kansas River cross sections in which $M$ ranges from 2.4 to 89 .

Maximum depth and mean annual discharge at the same cross sections (fig. 16) have a somewhat similar relation, for the river with the greatest variation in $M$ has the greatest variation of maximum depth with mean annual discharge.

Again the presence of dams on the rivers may be important. In addition to the Cedar Bluffs and Kanopolis Dams on the Smoky Hill River, there are two dams on the Republican River. The Trenton Dam, completed in 1955 , is located between cross sections 50 and 51, and the Harlan County dam, completed in 1952, is lo-

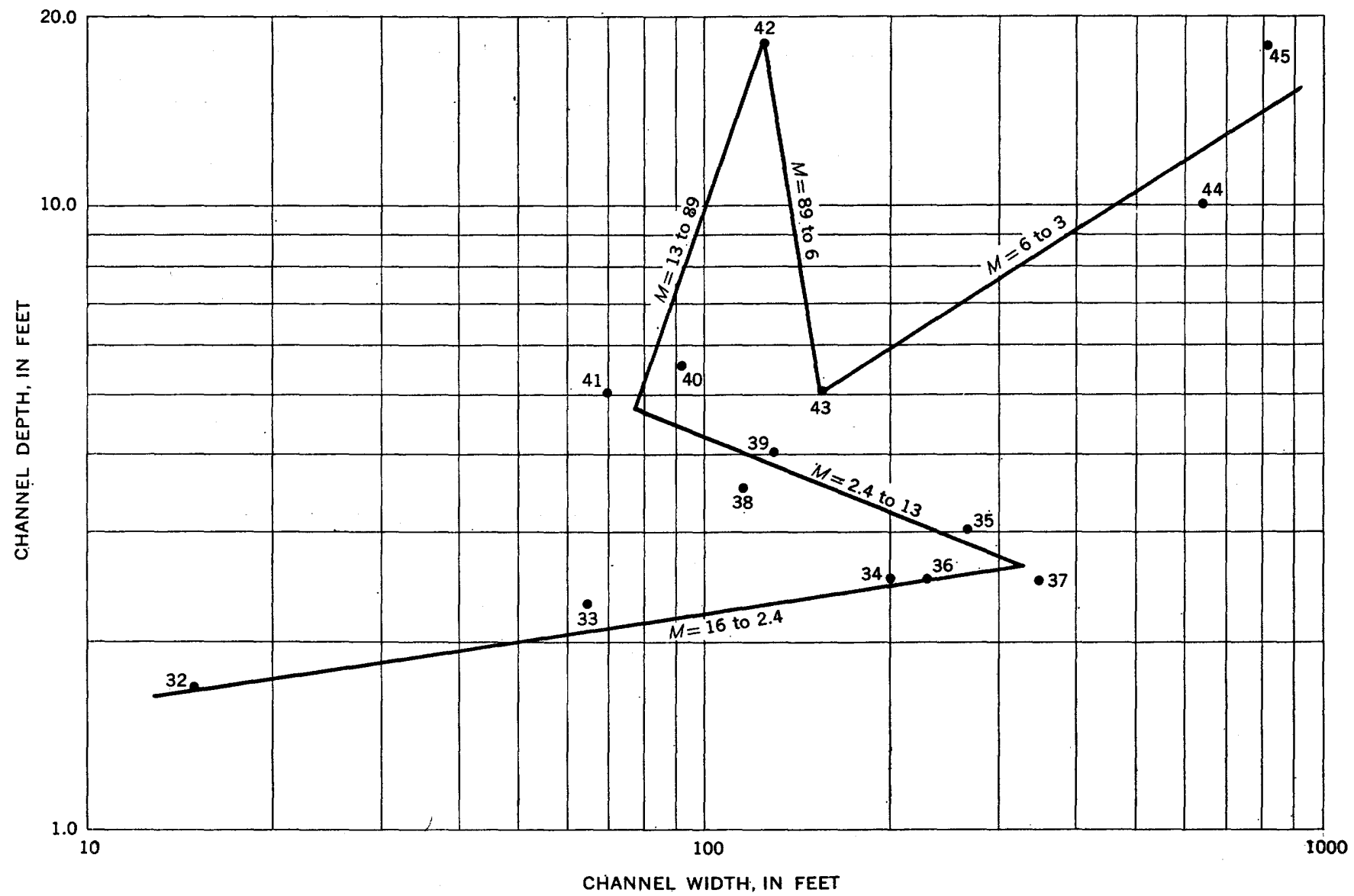

FIGURe 14.-Relation of channel width to depth for the Smoky Hill-Kansas River. Numbers refer to cross seetions listed in table 1. 
cated between cross sections 51 and 52. Any effects of these structures on the stream channels could have been expected before the cross sections were studied in 1958, and as mentioned above scour occurred at cross section 85 below the Cedar Bluffs Dam. In addition, channel degradation may also have occurred at cross section 86, a short distance below the Harlan County dam, for bedrock is exposed in the channel at that cross section.

In spite of the existence of the dams, if cross sections 37 through 41 were eliminated from the Smoky Hill River data and cross sections 50 through 52 were eliminated from the Republican River data the Smoky Hill River plots on figures 15 and 16 would still show great variation in contrast to the slight variation of the Republican River data. Therefore, although the effects of the dams should not be minimized, the writer believes that the cross-section data collected in 1958 and plotted on figures 15 and 16 were not significantly influenced by the structures, for the upstream cross sections were located several miles above the water level of the reservoir and none of the downstream sections were closer than 20 miles to the dams.

To summarize (see figs. 12-16) if $M$ remains constant downstream then the width and depth of the channel will increase at a uniform rate with discharge, excluding the influence of other variables, and width-depth ratio will remain constant. If $M$ increases, downstream channel depth will increase more rapidly than width, which may even decrease, and the width-depth ratio will decrease. If $M$ decreases, downstream channel width will increase more rapidly than depth, which may even decrease, and width-depth ratio will increase.

\section{CONCLUSIONS AND POSSIBLE APPLICATIONS}

This study suggests that $M$ represents the resistance to erosion or general behavior of sediment in a stream channel containing only small amounts of gravel. A study of this aspect of the physical properties of sediment is needed before it will be possible to suggest other than that the silt-clay acts as a binding agent in which

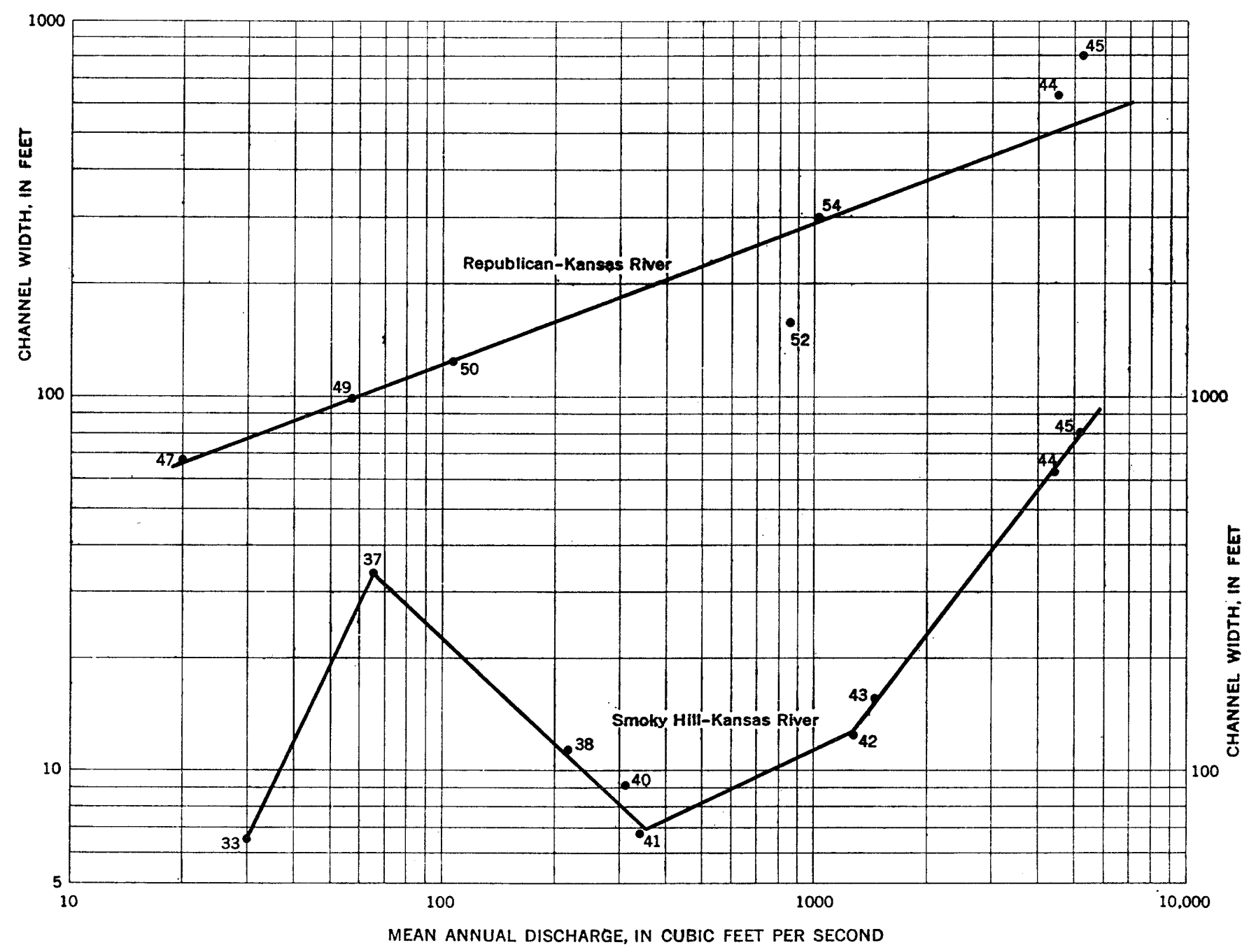

FigURE 15.-Relation of channel width to mean annual discharge for the Smoky Hill, Republican and Kansas Rivers. Numbers refer to cross sections listed in table 1. 


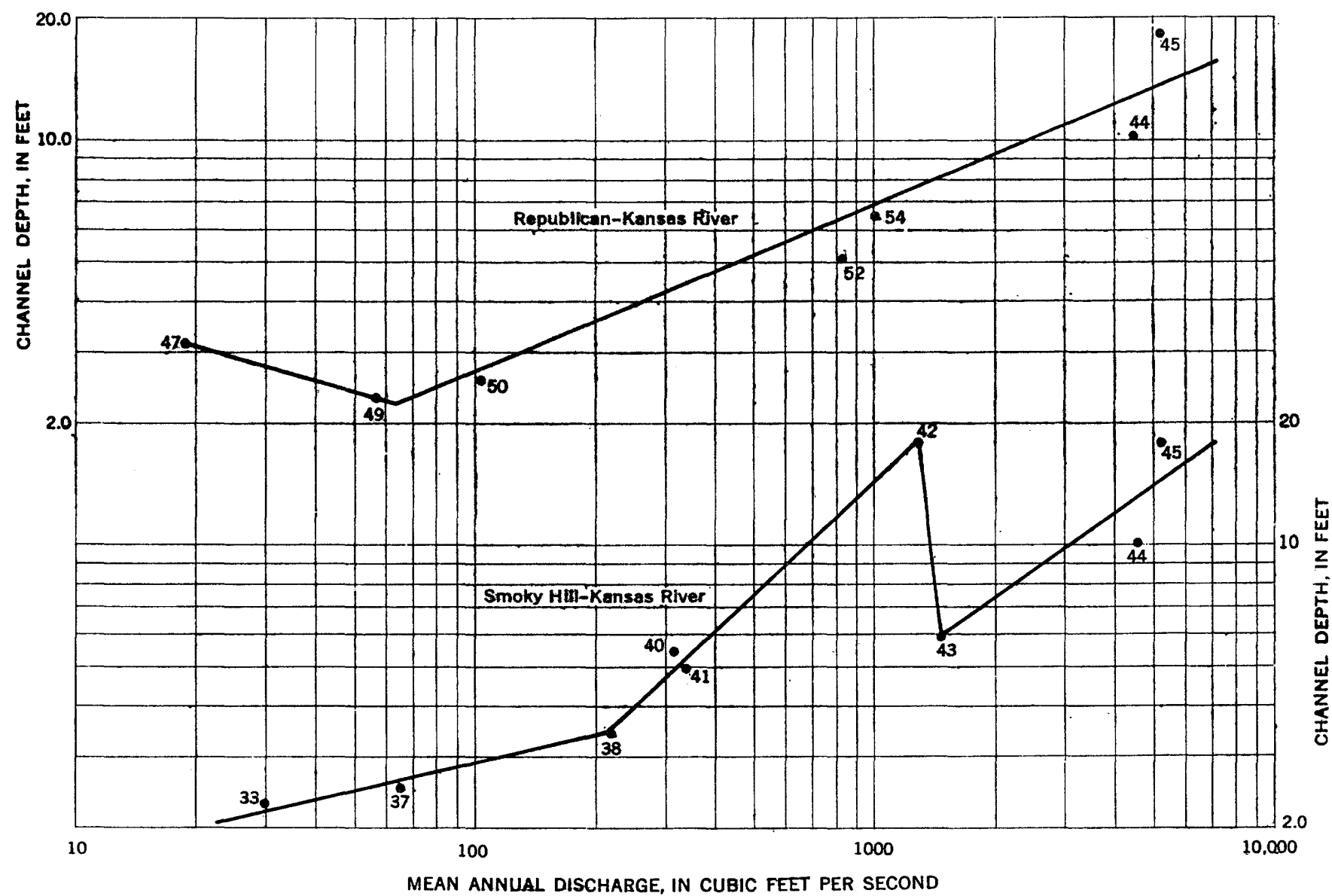

FIGURE 16.-Relation of channel maximum depth to mean annual discharge for the Smoky Hill, Republican, and Kansas Rivers. Numbers refer to cross sections listed in table 1.

the larger sediment grains are fixed. Undoubtedly, the type of clay present and the ratio of silt to clay are also important.

The importance of the percentage of silt and clay in the perimeter of a stream channel to channel shape has been demonstrated. As $M$ increases the widthdepth ratio decreases according to the following equation:

$$
F=255 M^{-1.08}
$$

Neither mean annual discharge nor mean annual flood affect this relation significantly, at least for the channels sampled in this study.

The relation of the unstable channels (fig. 10) suggests that the position of a point in relation to the regression line of figure 8 may indicate that aggradation or degradation is occurring within a channel. Aggrading channels will have a higher width-depth ratio than indicated by $M$; whereas degrading channels will have a lower width-depth ratio than indicated by $M$.

As $M$ increases downstream along a given river, the depth increases more rapidly and the width less rap- idly with discharge than if $M$ were constant downstream, and width-depth ratio decreases. Conversely as $M$ decreases downstream along a given river the depth increases less rapidly and the width more rapidly with discharge than if $M$ were constant, and width-depth ratio increases. Changes in $M$ downstream along the Smoky Hill-Kansas River system support the conclusion that width-depth ratio varies with $M$ regardless of discharge, and whereas both width and depth of a channel may increase with discharge, a change in $M$ along the river will change the rate of their increase downstream and may even cause either width or depth to decrease downstream.

The use of percentage of silt and clay in sediment or some similar parameter, as an indication of the physical properties of alluvium, seems to open several profitable lines of research into fluvial morphology. For example, perhaps $M$ may be of more value in studies of longitudinal stream profiles than median grain size. The adjustment of the cross sections of a stream to changed hydrologic conditions by widening or deepening of the channel may be related to $M$. In 
addition, it may be possible to use the regression line of figure 8 and the equation derived therefrom to aid in the prediction of the stable form of canals or rivers subjected to different types of modification or increased discharge.

\section{REFERENCES}

Bagnold, R. A., 1954, The physics of blown sand and desert dunes: London, Methuen \& Co., 265 p.

Boyoucos, G. J., 1935, The clay ratio as a criterion of susceptibility of soils to erosion: Am. Soc. Agronomy Jour., v. 27, p. 738-741.

Burmister, D. M., 1952, Soil mechanics: New York, Columbia Univ. Press, $155 \mathrm{p}$.

Fisk, A. N., 1944, Geological investigation of the alluvial valley of the Lower Mississippi River: U.S. War Dept., Corps of Engineers, Vicksburg, Miss., $78 \mathrm{p}$.
Hjulstrom, Filip, 1935, Studies of the marphological activity of rivers as illustrated by the River Fyris: Geol. Institution, Univ. Upsala Bull. [Sweden], v. 25, p. 221-527.

Lacey, Gerald, 1930, Stable channels in alluvium: Inst. Civil Engineers Proc., v. 229, p. 259-285.

Lane, E. W., 1937, Stable channels in erodible material: Am. Soc. Civ. Eng. Trans., v. 102, p. 123-142.

Leopold, L. B., and Maddock, Thomas, Jr., 1953, The hydraulic geometry of stream channels and some physiographic applications: U.S. Geol. Survey Prof. Paper 252, 57 p.

Rubey, W. W., 1933, Settling velocities of gravel, sand, and silt particles: Am. Jour. Sci., 5th series, v. 25, p. 325-338. 1952, Geology and mineral resources of the Hardin and Brussels quadrangles (in Illinois): U.S. Geol. Survey Prof. Paper 218, $179 \mathrm{p}$.

Trask, P. D., 1959, Effect of grain size on strength of mixtures of clay, sand, and water: Geol. Soc. Am. Bull., v. 70, p. 569-580. 
